\title{
1868 EN LA MEMORIA CARLISTA DE 1931: DOS REVOLUCIONES ANTICLERICALES Y UN PARALELO
}

\author{
POR \\ Antonio Manuel Moral Roncal \\ Profesor Contratado Doctor del departamento de Historia II, Área de Historia Contemporá- \\ nea, Facultad de Filosofía y Letras, Universidad de Alcalá de Henares

\section{RESUMEN} \\ El presente artículo analiza la cuestión religiosa en 1868 y, especialmente, \\ 1931 prestando atención central al papel que ésta tuvo como elemento de ruptura \\ y factor movilizador de la reacción contrarrevolucionaria que el carlismo lideró \\ en España durante la Segunda República.
}

PALABRAS ClAVE: España, siglos XIX y XX, Segunda República, Carlismo, Política Anticlerical, Prensa contrarrevolucionaria.

\begin{abstract}
This article analyses the role during 1868 and, especially, 1931 the religious matter placed as an elemento of ruptura and factor of mobilization for the counterrevolution that Carlism directed in Spanish Second Republic.
\end{abstract}

KEY WordS: Spain, XIXth and XXth Century, Second Republic, Carlism, Anticlerical policy, Counterrevolutionary Press.

Recibido/Received 27-01-2007

Aceptado/Accepted 02-03-2007

No padecería España la inmensa desgracia actual si, en vez de perseguirnos y pisarnos, las famosas derechas hubiesen tenido como centro de gravedad a quienes fueron siempre la Guardia Civil de la Iglesia» ${ }^{1}$.

\footnotetext{
${ }^{1}$ Baronesa de Guecho-Martiartu, El Cruzado Español, 14 de agosto de 1931, p. 1.
} 


\section{CATÓLICOS Y TRADICIONALISTAS ANTE DOS VICTORIAS REVOLUCIONARIAS}

En el siglo XX, antes de la proclamación de la Segunda República, los intentos para levantar y sostener un partido católico de ámbito nacional en España habían fracasado por diversas causas, entre las que destacaron la falta de apoyos cualitativos (doctrinales, propagandísticos), de líderes adecuados y de un pronunciamiento claro y decisivo de la máxima autoridad eclesiástica en este asunto, es decir, del Director Pontificio de Acción Católica española². Meses antes de la caída de Alfonso XIII, el cardenal Segura intentó potenciar la unión de los católicos en el terreno político con el objetivo de presentar una gran coalición que pudiera frenar el viento del republicanismo, identificado con un claro anticlericalismo. Pero ni el primado ni el resto de la jerarquía española otorgaron nunca un apoyo tan expreso y claro como el que recibió Acción Nacional durante el mes de mayo de 1931. A partir de entonces, las posibilidades de crear un gran partido católico aumentaron considerablemente. Sus cuadros iniciales de dirigentes provinieron de los distintos sectores del catolicismo español -aunque predominaron los miembros de la Acción Católica Nacional de Propagandistas- que pronto decidieron como primer objetivo la obtención de apoyos electorales suficientes para salir victoriosos de las urnas ${ }^{3}$. De ahí la necesidad de acercamiento a los integristas y a los carlistas, como señalaron algunos líderes. Si el anticlericalismo era un elemento de cohesión entre los diversos grupos políticos de las izquierdas españolas ${ }^{4}$, a ojos de algunos católicos la defensa de la religión debía ser el común denominador de las derechas 5 .

2 La novedad ocurrió al nacer la Segunda República, como subrayó el artículo «Los católicos ante el momento actual» publicado en El Siglo Futuro el 6 de mayo de 1931 como comentario a una carta pastoral de Segura: «El eminentísimo cardenal primado, en su calidad de Director Pontificio de la Acción Católica, da, además, normas a los católicos para su actuación en el orden religioso y en el orden político, pues en todos ellos tienen deberes que cumplir (...). Las palabras del Director Pontificio de la Acción Católica son tan claras que no necesitan comentarios, y tan conmovedoras y apremiantes que a todos han de estimularnos a trabajar sin descanso».

3 J. L. RuIZ SÁNCHEZ, «La unión política de los católicos españoles. Factores para la creación de un partido nacional», en J. Aurell y P. PÉREZ LóPEZ (Eds.), Católicos entre dos guerras. La historia religiosa de España en los años 20 y 30, Madrid, Biblioteca Nueva 2006, pp. 47-59.

${ }^{4} \mathrm{El}$ anticlericalismo fue el principal elemento de unión entre las izquierdas españolas en los años treinta para algunos historiadores, como M. Álvarez TARDío, Anticlericalismo y libertad de conciencia, Madrid, Centro de Estudios Políticos y Constitucionales 2002.

5 Idea manifestada en J. AvILÉs, «Catolicismo y derecha autoritaria. Del maurismo a Falange española» en P. Aubert, Religión y sociedad en España (siglos XIX y XX), Madrid, Casa de Velázquez, 2002. Sobre la situación de la Iglesia en la coyuntura republicana ver M. BAtLlori y V. M. ARBELOA, Arxiu Vidal i Barraquer. Església i Estat durant la Segona República Espanyola, 1931-1936, Montserrat, Abadía de Montserrat 4 tomos en 9 volúmenes, 1971-1991; W. J. CALlaHAN, La Iglesia católica en España (1875-2002), Barcelona, 2003; F. LANNON, Privilegio, persecución y profecía. La Iglesia Católica en España, 1875-1975, Madrid, Alianza 1990; F. de MeER, La cuestión religiosa en las Cortes Constituyentes de la II República española, Pamplona, Eunsa, 1975; J. L. Orella, Víctor Pradera:

Hispania Sacra, LIX

119, enero-junio 2007, 337-361, ISSN: 0018-215-X 
Esa búsqueda de apoyos en las distintas corrientes ideológicas más o menos afines no fue en absoluto una novedad, pues durante los últimos años del reinado de Isabel II, y durante el Sexenio Democrático, los neocatólicos habían cerrado filas con los legitimistas. El 12 de diciembre de 1868, La Esperanza, el principal y autodefinido periódico monárquico-católico, había comunicado a sus lectores la creación de una Asociación de Católicos, cuya junta directiva estaba formada por el marqués de Viluma (moderado), el conde de Orgaz (carlista), el conde de Vigo (moderado), León Carbonero Sol (neocatólico), Francisco José García (carlista), Ramos Vinader (carlista) y Enrique Pérez Hernández (moderado), para defender a la Iglesia de la nueva legislación religiosa de los triunfantes revolucionarios ${ }^{6}$. En un principio, sin ningún carácter político, aunque sus lectores confiaron que sería el primer paso para lograrlo.

«Excusado es decir que llamándonos y siendo católicos esta Asociación, no solamente esquiva, sino que rechaza cuanto pueda dar ni aun sombra de pretexto para que se le confunda con ningún partido político: o, lo que es igual, lo que se llama política en el sentido concreto y usual de la palabra, está formalmente excluido del espíritu y letra del objeto y del fin de la Asociación. Sabemos desde ahora que se intentará negarlo; conocemos todo el interés que habrá en aparentar desconocerlo; pero ante Dios y ante la patria aseguramos que esta es la verdad. (...) Esperemos que con la bendición de Dios esta empresa fructificará como lo desean sus autores, eco fiel en esta ocasión del común deseo de los buenos católicos españoles» 7 .

La principal causa de esta convergencia de afines había sido el estallido de un evidente anticlericalismo, protegido y amparado por las agrupaciones revolucionarias de las ciudades, denunciado inmediatamente en la prensa carlista.

«Las juntas revolucionarias no han hecho sino destituir funcionarios y nombrar otros en su lugar; en unas partes se ha prohibido a los párrocos el cobro de derechos, al paso que se proclamaba la necesidad de proteger al clero parroquial; en otras se ha prohibido, bajo penas severas, cierto género de limosnas, apoderándose de ellas; aquí se ha legislado sobre la bula de la Santa Cruzada; acullá sobre las dispensas matrimoniales. Solo ha habido uniformidad en cuanto a decretar derribos de iglesias, expulsión de frailes, supresión

Un católico en la vida pública de principios de siglo, Madrid, BAC 2000; G. REDONDO, Historia de la Iglesia en España, 1931-1939, 2 vols., Madrid, Rialp 1992; J. L. RODRíGUEZ JiMÉNEZ, La extrema derecha española en el siglo XX, Madrid, Alianza 1997.

6 «Trátese, pues, de la organización de fuerzas que han de emplearse en el fin exclusivo de propagar y defender las doctrinas, las instituciones y el influjo social de la Iglesia, señaladamente su libertad y la unidad católica de España. Los medios que para el logro de este fin ha de emplear la Asociación Católica, no pueden ser sino legítimos, legales y morales. Por las vías de la paz, y bajo el amparo de la ley, ha de proceder siempre en el ejercicio y en la defensa de sus derechos.» La Esperanza, 12 de diciembre de 1868.

${ }^{7}$ Idem. 
de congregaciones y clausura de conventos, todo, por supuesto, en nombre de la liber$\operatorname{tad} »^{8}$.

Ese anticlericalismo fue asumido por el Gobierno Provisional para evitar, de esta manera, actos incontrolados y violentos de bandas armadas contra eclesiásticos y lugares de culto. Y es que hasta en la propia oficialidad alzada se había instalado una irreligiosidad nada desdeñable, de tal manera que no resulta extraño que el Sexenio Revolucionario marcara, en muchos aspectos, un verdadero punto de inflexión en la trayectoria del anticlericalismo decimonónico, presenciando la madurez y el cenit de una de las corrientes del mismo -la popular-, así como el germen de otra -la intelectual-a la que se debía sumar la castrense ${ }^{9}$.

En el mes de noviembre de 1868, se decretó la disolución de las Juntas, lo cual provocó levantamientos en Andalucía que reprimió el Ejército. Pese a esa medida moderadora, el principal órgano de prensa carlista -el periódico La Esperanza-reaccionó defendiendo los privilegios y el papel social de la Iglesia en España, criticando las nuevas leyes y decretos como la libertad de cultos y de asociación ${ }^{10}$. Entre octubre y diciembre, el periódico carlista dirigió tanto sus críticas como sus peticiones de moderación al ministro de Gracia y Justicia, Antonio Romero Ortiz, principal impulsor de la política anticlerical. Su actividad legislativa pareció imparable: el 12 de octubre firmó un decreto suprimiendo la Compañía de Jesús en España y territorios ultramarinos; el 18 del mismo mes proclamó extinguidos todos los monasterios, conventos, colegios, congregaciones y demás casas de religiosos de ambos sexos fundados desde el 29 de julio de 1837; además, fueron decretadas al menos 71 disposiciones gubernamentales para organizar una enseñanza estatal y laica, derogando la ley de 2 de junio de 1868 por la que se había cedido la tutela de la primera enseñanza a la Iglesia Católica.

La Esperanza inició una campaña de cartas abiertas al Gobierno -aunque en su mayoría dirigidas al ministro Romero Ortiz- solicitando la suspensión de toda medida referida a la Iglesia hasta que las Cortes Constituyentes se pronunciaran al respecto. Fueron sus autores destacados obispos y arzobispos que, de esta manera, trataron de definirse públicamente ante la política religiosa procurando, igualmente, influir en la actitud del Gobierno respecto a la Iglesia, lo

${ }^{8}$ La Esperanza, 20 de octubre de 1868, p. 3.

9 J. M. CuenCa Toribio, «Un posible punto de partida para el análisis de una cuestión clave de la historia española contemporánea: el anticlericalismo», en su Catolicismo contemporáneo de España y América. Encuentros y divergencias, Madrid, Ediciones Encuentro 1999, pp. 101-102.

${ }^{10}$ La Esperanza, 21 de octubre de 1868. Un acercamiento inicial a este periódico tan significativo del movimiento carlista es Federico GutiérRez, El padre Claret en el periódico La Esperanza, Madrid, Publicaciones Claretianas 1987.

Hispania Sacra, LIX

119, enero-junio 2007, 337-361, ISSN: 0018-215-X 
cual fue interpretado por los liberales como una injerencia política de los prelados ${ }^{11}$. La disolución de las Conferencias benéficas de San Vicente de Paúl fue el hecho que hizo desbordar el silencio inicial de la jerarquía, pero siempre de forma personal, nunca como una declaración formal del conjunto de obispos, sorprendiendo a algunos que, por ello, no firmara ninguna carta el Primado. La postura inicial evitó la confrontación, intentando influir en los nuevos gobernantes, advirtiéndoles de sus «errores» en materia eclesiástica. Aunque, según avanzaron las semanas, comenzó a detectarse en las cartas cierta crispación, mientras el periódico carlista denunciaba que el anticlericalismo suponía un atentado contra la unidad histórica de los españoles, basada, desde los tiempos visigodos, en la unidad religiosa ${ }^{12}$. Asimismo, los tradicionalistas denunciaron la falta de libertad de la Iglesia en el nuevo régimen, lo que contrastaron con sus evidentes presupuestos liberales y demócratas ${ }^{13}$.

Con el paso de los años, la cuestión religiosa -y la división de los españoles respecto a ella- fue una de las causas más importantes para el estallido de la Tercera Guerra Carlista (1872-1876). Incluso en las provincias vascas, donde la cuestión foral desvió la atención y, por tanto, relativizó el papel determinante jugado por el factor religioso, lo cierto es que la sublevación carlista tuvo éxito porque la población se congregó en defensa de los fueros, pero en cuanto éstos resultaban ser expresión y símbolo del catolicismo vasco, entendido como reserva espiritual de una España católica y tradicional que irremisiblemente se perdía ante los avances revolucionarios. Desde 1868 ese fue el mensaje que los líderes carlistas extendieron entre sus masas, y si tuvo éxito entre gentes llanas fue porque lo interiorizaron en esa clave, que vinculaba con el substrato más recóndito de la conciencia y cultura populares, el cual apelaba a la fe, aprendida de sus padres, como factor movilizador y a un cosmos mental tradicional hondamente enraizado ${ }^{14}$. A continuación, sólo faltó que los propagandistas legiti-

11 Entre el 31 de octubre y el 30 de diciembre de 1868 se publicaron 22 cartas en La Esperanza firmadas por los obispos de Jaén, Astorga, Tarazona, Burgos, Osma, Tortosa, Vitoria, Galicia, Tarragona, Salamanca, Córdoba, Plasencia y Barcelona, además de los arzobispos de Zaragoza, Valladolid y Granada.

${ }^{12}$ La Esperanza, 15 de octubre de 1868, p. 1. Idea que sería repetida continuamente durante el Sexenio Revolucionario en la prensa y propaganda carlista.

13 «Tenemos sufragio universal...; Libertad de asociación y de reunión, violada únicamente en contra de los Jesuitas, de los socios de San Vicente de Paúl, de los frailes y monjas en general; libertad religiosa, o, para hablar con más exactitud libertad para decir y hacer todo lo que pueda redundar en perjuicio del catolicismo», La Esperanza, 2 de diciembre de 1868, p. 2.

14 A mediados del siglo XX, los historiadores españoles concedieron demasiada importancia a la defensa de los fueros, a la hora de analizar el fenómeno carlista, menguando la importancia histórica de la religión y las mentalidades. Sin embargo, desde hace veinte años se ha producido una nueva relectura del factor religioso en la extensión popular de la ideología legitimista. Ver C. RuBio PoBES, «¿Qué fue del oasis foral? (Sobre el estallido de la Segunda Guerra Carlista en el País Vasco)», Ayer 38 (2000), pp. 65-89; Id., «El poder del púlpito. El contencioso sobre las publicatas civiles y la politización del clero en la primera mitad del siglo XIX», Historia Contemporánea, 21, (2000), pp. 183-204. 
mistas advirtieran que la defensa de los fueros y de la religión únicamente podía ser garantizada por la Monarquía tradicional y popular que encarnaba Carlos VII de Borbón, la cual era popular porque era católica.

Bajo el régimen de la Restauración, la amalgama contrarrevolucionaria se deshizo, aunque esas fuerzas volvieron a actuar al unísono, conjuntadas o coaligadas -sobre todo en momentos críticos- en aquellos lugares donde había una formación política confesional diocesana ${ }^{15}$. Así, carlistas e integristas participaron en la formación de la Liga Católica de Sevilla y unieron sus fuerzas electorales en determinadas circunstancias, pero nunca de manera permanente. Sin embargo, tras la proclamación de la Segunda República, y especialmente ante el debate sobre la futura Constitución, la unión de los católicos resultó más fundamental que nunca. Como señaló El Siglo Futuro, el 24 de abril de 1931, se trataba «de ser o no ser» 16 .

De esta manera, desde el principio, el principal órgano de prensa del integrismo se mostró favorable a la unión política de los católicos, sin que por ello cediera en sus principios ideológicos. A ojos de muchos observadores, esta inicial línea moderada del periódico sintonizó con la incipiente postura del Pretendiente carlista. Don Jaime de Borbón, desde París y por mediación de su jefe delegado, el marqués de Villores, anunció, en unas declaraciones recogidas en numerosos diarios, que aconsejaba a todos sus fieles seguidores que ayudaran al Gobierno Provisional en el mantenimiento del orden público y la salvaguardia de los lugares de culto, hasta que hubiera elecciones a Cortes Constituyentes y se formara una parlamento verdaderamente nacional. No obstante, esta inicial actitud conciliadora del hijo de Carlos VII varió categóricamente a medida que se produjeron graves manifestaciones de anticlericalismo en España.

A través de El Siglo Futuro, los integristas continuaron afirmando su antiliberalismo y criticando las cesiones de los católicos liberales pero, llegado el momento, manifestaron también que su actitud y conducta serían las salvaguar-

15 J. de la Cueva Merino, «Clericalismo y movilización católica en la España de la Restauración» en J. de la CUEVA y A. L. LóPEZ VillaVERde (coords.), Clericalismo y asociacionismo católico en España. De la Restauración a la Transición, Cuenca, Universidad de Castilla La Mancha 2005, pp. 2750 .

${ }^{16}$ El Siglo Futuro (1875-1936) era un diario secundario en Madrid, pero de indudable influencia en medios tradicionalistas, siendo también leído en provincias. Tenía una tirada de 6.000 ejemplares según la estadística de 1927. Fue más combativo que El Universo, viejo diario integrista, reducido a semanario en 1926, muy cercano a la Acción Católica de Herrera Oria y a sus planteamientos ante la República. El cardenal Segura, como contraste, aseguró a Pedro Sainz Rodríguez que nunca había leído más periódico que El Siglo Futuro. Un estudio veterano sobre esta empresa, F. CARANTOÑA, El Siglo Futuro, diario de Madrid, Madrid, Imprenta de Prensa Castellana, 1955. Asimismo, resulta imprescindible C. BARreiro Gordillo, El carlismo y su red de prensa en la Segunda República, Madrid, Actas 2003, aunque la autora centra su investigación más detalladamente en la evolución política del carlismo que en la problemática católica.

Hispania Sacra, LIX

119, enero-junio 2007, 337-361, ISSN: 0018-215-X 
dadas durante el fenecido régimen constitucional. Manifestaron abiertamente que no regatearían por su parte su concurso a todo empeño, a toda concentración, que tuviera por fin la defensa y la restauración de los principios católicos en España ${ }^{17}$. Para ese objetivo resultaba vital la preparación del próximo envite electoral, por lo que desde su periódico incitaron a todos los católicos, en primer lugar, a registrarse en el censo electoral y a verificar su posibilidad de vo$\operatorname{tar}^{18}$. La Constancia de San Sebastián, diario también integrista, le secundó en sus propósitos.

A diferencia de la prensa carlista -El Pensamiento Navarro de Pamplona ${ }^{19} \mathrm{y}$ El Correo Catalán de Barcelona-, recelosa y crítica con El Debate, los integristas como El Siglo Futuro publicaron extractos de las editoriales y artículos del periódico de Herrera Oria, al que apoyaron en sus intentos de unión del voto católico, subrayando las convergencias en comentarios y objetivos ${ }^{20}$. El 29 de abril de 1931, el principal periódico integrista anunció la creación de Acción Nacional en Madrid como alianza electoral, no como partido político, por lo que, la semana siguiente, apoyó públicamente sus candidaturas para las elecciones constituyentes.

«Nuestra personalidad y nuestra significación no desaparecen ni se esfuman, porque a ese común esfuerzo aportamos nuestra cooperación como lo que somos, y porque con independencia de ese bloque, nuestras organizaciones deben subsistir, reforzándose si es posible, y propugnando y sosteniendo en ellas nuestro programa católico y tradicional. Así pues, en los momentos actuales nuestra línea de conducta es clara: sigamos siendo lo que siempre fuimos y hoy más que nunca debemos ser; pero al mismo tiempo en la próxima campaña electoral trabajemos con toda decisión sin regatear ni las fuerzas, ni los entusiasmos, ni los medios económicos con la coalición llamada Acción Nacional o con cualquier otra similar a ella en las provincias». A partir de esa fecha, Acción Nacional publicó varios anuncios y convocatorias en El Siglo Futuro, solicitando la colaboración de sus lectores, actuando como interventores en las rectificaciones del censo, trabajando en tareas de propaganda y consolidación de su programa, logrando cuotas para sufragar los gastos de campaña o recogiendo

17 «Los deberes de la hora presente» en El Siglo Futuro, 22 de abril de 1931, p. 1. Tres días más tarde volvían a confirmar las mismas ideas en «A las Constituyentes. Hay que trabajar sin descanso». Igualmente el día 27 de abril en el artículo «Insistiendo. Pensando en el porvenir de España».

18 El Siglo Futuro, 27 de abril de 1931, p. 1; en el mismo sentido se manifestaron en las semanas siguientes y, prácticamente, hasta las jornadas electorales del mes de junio.

19 Durante la Segunda Republica este periódico tuvo una tirada cercana a los 3.900 ejemplares, frente a La Unión de Sevilla, también tradicionalista, con 5.000, El Pensamiento alavés con 3.000, El Correo Catalán con unos 4.000 aproximadamente.

${ }^{20}$ Por ejemplo en El Siglo Futuro, 28 de abril de 1931, se señaló que el editorial de El Debate titulado «Un gran sacrificio colectivo» ampliaba lo apuntado el día anterior en sus páginas. 
donativos con el mismo fin. La dirección del periódico, por su parte, continuó aconsejando a los integristas la cooperación con la agrupación electoral, sobre todo tras la publicación de su manifiesto del 7 de mayo.

Sin embargo, la reunión de los afines no resultó fácil en absoluto, de ahí que Acción Nacional no fuera un partido político sino una agrupación electoral que defendía los grandes principios de Dios, Patria, Orden, Familia y Trabajo. La principal causa de esta situación la tuvieron fundamentalmente los carlistas y los monárquicos partidarios de Alfonso XIII. De esta manera, la defensa de la Monarquía apareció como el motivo fundamental de las diferencias entre los distintos grupos católicos. Para las citadas corrientes ideológicas resultaba fundamental su defensa, pero para otras -más favorables a la accidentalidad de los regímenes políticos- no parecía imprescindible. En esta última se encuadraron inicialmente los integristas, los cuales consideraron que lo primero era defender los derechos imprescindibles de Dios en la sociedad y en el Estado, pues todo lo demás resultaba circunstancial, idea que publicó reiteradamente El Siglo Futuro $^{21}$. Este periódico confirmó el accidentalismo de las formas de gobierno a comienzos del mes de mayo, apoyándose además en la Carta Pastoral del cardenal Segura, cuyas instrucciones corroboraban no sólo «nuestro criterio y nuestra resuelta actitud, sino que tienen la fuerza de un mandato que todos, todos los católicos, sin excepción ninguna debemos cumplir, seamos monárquicos o republicanos, cualesquiera que sean nuestras convicciones políticas, pues a todos, en cuanto a católicos, nos obligan aquellas instrucciones»22.

Aunque en los días siguientes, como consecuencia de una contestación al alfonsino $A B C$, el periódico integrista hizo profesión de fe en la Monarquía Tradicional, no dejó de reconocer que por encima de ella se encontrarían siempre la Religión y la Patria, a las cuales la Monarquía estaba subordinada ${ }^{23}$. Tras lo cual animó al periódico conservador -y a sus apoyos sociales- a sumarse a Acción Nacional. También en 1868, La Esperanza se había mostrado partidaria de la tradición y más contraria al liberalismo que a un régimen político determinado:

«Nosotros, señores liberales, republicanos y no republicanos, somos monárquicos de corazón y de cabeza; pero no detestamos la república, no la condenamos ni podemos condenarla en absoluto; lo que detestamos es el liberalismo, guardando, sin embargo, en el pecho tesoros inagotables de compasión por los liberales. Vémosles divididos en dos campos: de una parte a los liberales republicanos, con sus principios absolutos, que no aceptamos; de otra a los liberales monárquicos, con su eclecticismo insoportable, y se nos dice: Elegid entre ambos; a lo cual contestamos sin vacilar: Vengan los primeros» 24 .

${ }^{21}$ El Siglo Futuro, 24 de abril de 1931,p. 1.

22 «Los católicos ante el momento actual» en El Siglo Futuro, 6 de mayo de 1931.

23 «Cuestiones de interés. Nuestra adhesión a la Acción Nacional», El Siglo Futuro, 8 de mayo de 1931.

${ }^{24}$ La Esperanza, 29 de octubre de 1868.

Hispania Sacra, LIX

119, enero-junio 2007, 337-361, ISSN: 0018-215-X 
Sin embargo, la prensa más férreamente carlista en 1931 -en esos momentos llamada jaimista por el nombre del Pretendiente- se mostró defensora a ultranza del régimen monárquico tradicional, incontaminado de virus liberal, como había sido habitual en su trayectoria política. Además, -frente a las llamadas a la unidad-inicialmente hubo quienes aconsejaron mantener la bandera de la legitimidad en la más absoluta soledad, para evitar la disolución de sus principios ideológicos en una amalgama conservadora ${ }^{25}$. El carlismo reafirmó con más fuerza que nunca su convencimiento absoluto de ser la Causa Católica, la única y verdadera. Al igual que en 1868, los jaimistas creyeron estar en los umbrales de una época de expansión y crecimiento, por lo que su fe en la victoria y el triunfo comenzó, lentamente, a brotar entre sus filas, aunque también cierto temor defensivo al desbordamiento revolucionario ${ }^{26}$. Éstos serían los dos rostros del Jano tradicionalista durante la Segunda República.

No obstante, los mismos ardientes defensores de la soledad en el combate manifestaron su predisposición a trabajar en labores sociales con el resto de católicos, pero nunca en una coalición política. Pero, al ser una de las características históricas del legitimismo monárquico, su atomización endógena, en los mismos periódicos y semanarios aparecieron también voces a favor de la unidad de acción, aunque desde su particular óptica: invitando a los afines a que se unieran a los principios carlistas ${ }^{27}$. No obstante, pese a estas declaraciones, hubo también quienes ampliaron su oferta de colaboración electoral: la Junta Regional legitimista de Navarra convino aliarse con todas aquellas organizaciones que se unieran en defensa de los intereses religiosos y forales del Viejo Reino ${ }^{28}$.

Por ello, en las primeras semanas del cambio político, más que una alianza con los católicos -muchos de ellos tildados como «místico-liberalizantes»-, los órganos de prensa carlista comenzaron a solicitar la unión de los monárquicos tradicionalistas (mellistas, integristas, legitimistas), tras lo cual, optimistamente, hubo quien predijo la suma de los alfonsinos, ya que la lógica de los hechos y la fuerza de las circunstancias debían contribuir también a que todos los miembros de la Casa de Borbón se unieran en el destierro, reconociendo el primordial derecho de don Jaime para regir a cuantos acataban su soberanía ${ }^{29}$.

\footnotetext{
25 «Normas de acción: ¡isolos y puros!!», F. A. Giménez, El Cruzado Español, 17 de abril de 1931, p. 5.

26 Sobre estas resurrecciones políticas del carlismo ver A. M. MoRAL RonCAL, Los carlistas, Madrid, Arcolibros 2002; Id., Las guerras carlistas, Madrid, Sílex 2006, pp. 187-198 y 291-297. Asimismo, Jordi CANAL, Banderas blancas, boinas rojas, Madrid, Marcial Pons 2006.

27 J. Ramiro, «Espíritu de sacrificio», El Cruzado Español, 17 de abril de 1931,p. 8.

${ }^{28}$ En el fondo eran estrategias de movilización electoral de la población practicadas anteriormente, las cuales habían demostrado la capacidad del jaimismo para ser un partido de masas, como señaló Javier UGARTE, «El carlismo hacia los años treinta del siglo XX. Un fenómeno señal», Ayer 38, (2000), p. 175.

29 «Ante el porvenir. Unión y acción», El Cruzado Español, 24 de abril de 1931, p. 1.
} 
Desde el semanario El Cruzado Español se defendió, en este sentido, la creación de un Frente Monárquico contra el Frente Revolucionario, bajo la bandera del tradicionalismo, siguiendo los consejos del Pretendiente en su manifiesto a los españoles, firmado el 22 de abril ${ }^{30}$.

Si en 1868, la prensa carlista había tenido sus diatribas pero también sus invitaciones a la unidad con el moderado isabelino La Época, en 1931 se instigó al alfonsino $A B C$ y a sus lectores a abandonar cualquier esperanza en una posible Restauración. Lentamente, comenzaron a producirse los encuentros y las fusiones entre algunos de estos grupos políticos, antes de la muerte de don Jaime, contrariamente a lo que algunos historiadores habían afirmado hasta el momento. El 10 de mayo, la Junta General de la Sociedad Tradicionalista Lealta (sic) Guipuzcoana aprobó su fusión con los carlistas de la provincia ${ }^{31}$. En las siguientes semanas se unieron los integristas y los legitimistas navarros, mientras se anunciaban conversaciones entre mellistas y carlistas en Gerona; se reorganizaron las fuerzas tradicionalistas en Valencia; en Barcelona las tres familias tradicionalistas realizaron actos de aserción conjuntamente y las juventudes integristas y jaimistas organizaron mítines de afirmación católica en el mismo Madrid $^{32}$. El semanario Criterio, dirigido por Luis Hernando de Larramendi, también se manifestó a favor de la unidad, trabajando para ampliar esa alianza no sólo en la escena política de las Cortes sino a nivel local ${ }^{33}$. A finales de año, los integristas y mellistas madrileños propusieron la fusión a los jaimistas, adoptando el nombre de Comunión Tradicionalista ${ }^{34}$.

Pero conforme pasaron los meses, y se produjeron acontecimientos como la quema de conventos del mes de mayo, los líderes carlistas advirtieron que se presentaba una ocasión óptima para lograr aumentar sus bases e influencia si lograban atraer a todo el voto católico. De ahí los artículos, discursos y mani-

\footnotetext{
${ }^{30}$ Constancio, «Derechos y deberes. Republicanos o jaimistas», El Cruzado Español, 1 de mayo de 1931, p. 6. Este semanario (1929-1936), luego bisemanario madrileño, representó la corriente más purista del carlismo, enemiga de los acercamientos a los monárquicos alfonsinos. Era dirigido por José Cora y Lira y tuvo entre sus colaboradores a Dolores de Gortázar Serantes, fundadora de otro órgano de prensa legitimista, Las Margaritas, que no tuvo gran difusión por problemas económicos.

${ }_{31}$ Noticia que fue publicada en El Cruzado Español, 15 de mayo de 1931, p. 2. Días antes, El Siglo Futuro había publicado el programa político de los integristas guipuzcoanos: Dios y Fueros, 8 de mayo, p. 1.

32 Estas fusiones y acercamientos fueron anunciados en El Cruzado Español, 22 de mayo, p. 1; 15 de junio, p. 3; 28 de agosto, p. 2; 4 de septiembre, p. 5; 11 de septiembre, p. $6 ; 27$ de noviembre de 1931.

33 «Memoranda», Criterio. Revista semanal de orientación política y literaria, $\mathrm{n}^{\circ} 5,22$ de octubre de 1931, p. 1. Este semanario representó al carlismo más combativo frente a El Siglo Futuro, pero cesó en poco tiempo, tras la muerte de don Jaime y la proclamación de Alfonso Carlos I.

${ }^{34}$ Carta del presidente del círculo carlista, Lorenzo Sáenz al Pretendiente, 22 de diciembre de 1931. Archivo Histórico Nacional (en adelante, AHN), archivo carlista Borbón-Parma, correspondencia de Alfonso Carlos I, c. 105, exp. 2.
}

Hispania Sacra, LIX

119, enero-junio 2007, 337-361, ISSN: 0018-215-X 
festaciones que realizaron los legitimistas para que la jerarquía eclesiástica se convenciera de que los carlistas y su ideario eran la exclusiva bandera que le quedaba a la Iglesia Católica para su defensa ${ }^{35}$. La unión de católicos y monárquicos frenaría la revolución republicana y su degeneración, el comunismo, por lo que la afirmación monárquica resultaba imprescindible. Sin embargo, Acción Nacional no defendió públicamente ningún régimen político por lo que numerosos carlistas se manifestaron en contra de adherirse a dicha agrupación electoral, por defender la Familia, el Orden y la Propiedad bajo una bandera republicana que muchos de sus asociados no hace poco tiempo habían criticado ${ }^{36}$.

La necesidad de presentarse a las elecciones a Cortes Constituyentes hizo que la organización de Acción Nacional se realizara con suma rapidez, ocupando la mayor parte de los puestos más importantes los miembros de la Asociación Católica de Propagandistas. Sin embargo, Acción Nacional no logró un gran éxito electoral pues, de 471 escaños, la agrupación sólo logro 6 únicamente ${ }^{37}$. En la cámara se unieron a los agrarios formando una minoría de derechas que contaba con tan sólo 22 diputados. La prensa carlista del Norte prefirió apoyar una coalición católico-fuerista de José Luis de Oriol ${ }^{38}$.

Al imperar la mayoría aplastante de partidos de izquierda en la Cámara y ante la imposibilidad de influir en los ministros republicanos respecto a la Constitución y su posterior desarrollo legal, los católicos apostaron por la movilización de la opinión pública, tal y como ya se había empezado a hacer en los meses anteriores, pero, a finales de año, con mayor énfasis. Ya el 24 de abril de 1931, El Siglo Futuro había recordado que -aun teniendo que aceptar la fuerza de los hechos- la obligación política de los católicos como tales era procurar que la mayoría parlamentaria fuera católica ${ }^{39}$.

$\mathrm{Y}$, al igual que en los primeros años del Sexenio Revolucionario, la prensa se convirtió en la principal arma de esta campaña de concienciación católica. En Madrid, toda la prensa católica, no sólo El Debate, sino ABC, El Siglo Futuro, La Nación, Informaciones y La Época que, dejando en ocasiones aparte sus di-

\footnotetext{
35 «Ellos y nosotros. La justicia de Dios. ¡Impenitentes! ¡Ciegos!», El Cruzado Español, 24 de abril de 1931 , p. 8 .

36 Incógnito Leal, «La semana política», El Cruzado Español, 8 de mayo de 1931, p. 7.

${ }^{37}$ M. Montero, «Los propagandistas católicos y la opinión pública» en J. Aurell y Pablo PÉREZ LóPEZ, (Eds.), op. cit., pp. 61-87.

${ }^{38}$ El Pensamiento Navarro, 6 de mayo, 7, 14, 23, 24 y 30 de junio.

${ }^{39}$ El periódico apeló a la reflexión de los creyentes: «¿Tienen ya los católicos españoles formado juicio de la situación en que nos encontramos? ¿Han meditado sobre la trascendencia que en esta ocasión suprema que será memorable tiene la actitud que adopten en el momento decisivo de emitir su sufragio? ¿Han reflexionado acerca de la responsabilidad que van a contraer votando o absteniéndose de ejercer sus derechos políticos?» en «Con tiempo... las elecciones constituyentes», El Siglo Futuro, 24 de abril de 1931, p. 1 .
} 
ferencias, convergieron en el combate a favor del catolicismo ${ }^{40}$. En 1868, gracias a la nueva legislación liberal, en los últimos meses aparecieron 24 periódicos y revistas carlistas, doblando su número al año siguiente, a pesar de sus continuas críticas a la libertad de prensa que, para muchos legitimistas, era «la boca por la que hablaba Luzbel al mundo». En 1931, ante la imposibilidad de contar, por el momento, con otros medios de combate, hasta en las páginas de El Cruzado Español se fue defendiendo la importancia de esos medios, pues si querían triunfar, más que fusiles -que cuando llegase el momento, no dudaban que serían los que hablarían- lo que hacía falta en esos meses era aumentar significativamente el número de cabeceras carlistas ${ }^{41}$. Preocupación que se transparentó hasta en la cúpula política. En una carta dirigida a Francisco Melgar, la escritora tradicionalista Dolores de Gortázar, le comunicó sus intentos para crear un diario jaimista a nivel nacional:

«Lo del periódico diario me entusiasma y he de decirle que cuando usted me escribió, había formado una junta o comité gestor en Madrid para fomentar la publicación de EL CORREO ESPAÑOL inmediata, y a mi me nombraron de ese comité y para dirigir una página literaria si se llega a publicar, aparte de formar en la redacción diaria con mi trabajo. Por cierto que hemos enviado un mensaje al Señor que supongo en su poder. Me extraña que Ízaga no tenga actuación en la Junta y se muestre en reserva, me figuro que acaso por su destino no quiera manifestarse a las claras. Todo esto coincidió con lo salvaje de los incendios. Mas el domingo posterior, como lo teníamos acordado, celebramos con autorización del jefe regional una gran junta para organizar y continuar tratando lo del diario, que no se presenta mal. De El Cruzado se vendieron el viernes en la Puerta del Sol diez mil ejemplares y se agotó la tirada. Ya habrá leído usted mi artículo, muy fuerte. Los jesuitas se van de España y no se sabe siquiera dónde andan. ¿No sería mejor y rápida otra organización más práctica y decisiva? Los momentos son excelentes. La ola roja ya la tenemos en casa (...). Mas que la prensa, que también, se necesita otra cosa urgente... Ya me entiende usted. Con que Vesollas, Rodezno, los Martínez de Pamplona, Arana y otros acaudalados no fuesen míseros, en seguida se reunía lo del periódico sin apelar a nadie más» ${ }^{42}$.

40 Un resumen de la posición ideológica de la prensa en este tiempo se encuentra en A. CHECA GoDOY, Prensa y partidos políticos durante la II República, Salamanca, Universidad de Salamanca 1989. Este estudio es la base del capítulo sobre la prensa carlista de M. CRuZ SEOANE y M. Dolores SÁIZ, Historia del periodismo en España. 3. El siglo XX: 1898-1936, Madrid, Alianza 1996. Más original resulta el estudio de C. BARreiro Gordillo, La prensa monárquica en la Segunda República, Bilbao, Grafite 2004.

41 «Lo más trascendental. Influencia del periodismo» por Jaime Leal de la Alcarria, El Cruzado Español, 1 de mayo de 1931, p. 3.

42 Archivo Histórico Nacional (en adelante, AHN), archivo carlista Borbón-Parma, correspondencia de Jaime de Borbón, c. 134, exp. 4. Carta fechada el 18 de mayo de 1931. Dolores de Gortázar Serantes (León, 1872-Leganés, 1936), maestra y escritora, colaboró con la prensa tradicionalista y su traducción del Arte poética de Horacio fue premiada por la Real Academia Española. Escribió novela, poesía y teatro, fundando en Madrid la revista femenina de Acción Católica, titulada Roma, en 1912. Perteneció a la Asociación de Escritores y Artistas de España, recibiendo la Orden de la Legitimidad Proscripta por Jaime de Borbón como recompensa por su labor al frente de las Margaritas carlistas. Ver su nota necrológica en El Cruzado Español, 17 de abril de 1936, p. 3.

Hispania Sacra, LIX

119, enero-junio 2007, 337-361, ISSN: 0018-215-X 
Pero, además de los periódicos, otros instrumentos demostraron su utilidad, como las diversas asociaciones ciudadanas (Confederaciones de Padres de Familia, Estudiantes Católicos), en las cuales también participaron carlistas, con la aprobación del Pretendiente, como Abelardo López Peyró. El 23 de diciembre escribió a D. Alfonso Carlos:

«Se nota en España una fuerte reacción de derechas en todas partes y los católicos salen de la apatía en que antes estaban sumergidos. Reina en el país tranquilidad completa en cuanto a religión se trata y los conflictos sociales van desapareciendo poco a poco. Es cierto que existe alguna intranquilidad en los sectores obreros pero había muchos más, más fuertes y violentos en tiempos de la Monarquía.

Se han constituido en España Asociaciones de Familiares y Amigos de Religiosos. En Madrid se ha constituido una que abarca Castilla la Nueva y Extremadura y de ella me han nombrado presidente. Como existen ya en casi todas las provincias, nos hemos reunido los presidentes de las Juntas regionales y hemos constituido la Confederación Nacional de la que también me han nombrado presidente de toda España e igualmente presidente de su Comité Ejecutivo.

Existe un semanario que ha publicado mi fotografía y unas declaraciones y mañana se publicará otra segunda fotografía ya como presidente de la Confederación y en el número del jueves próximo se insertarán unas declaraciones mías abarcando ideas generales de nuestro programa a desarrollar, el que tendrá efecto dentro de los cauces jurídicos legales presentes. De estos periódicos le mandaré un ejemplar de cada uno de ellos, para que cuando sus múltiples ocupaciones se lo permitan pueda enterarse de ese movimiento que ha de tener gran importancia en nuestra querida patria» ${ }^{43}$.

Desde los círculos jaimistas se trató de organizar una respuesta femenina, potenciándose una Cruzada de Damas carlistas, en defensa del catolicismo y la Iglesia, pero también para ejercer la caridad, el socorro a los necesitados, el fomento de la educación y la cultura. En definitiva, se intentó atraer a la Comunión a la población femenina, al considerarse que su religiosidad se sentiría herida por la política republicana. Por otra parte, los jaimistas organizaron recogidas de firmas para protestar por medidas antirreligiosas en varias provincias. Los católicos también intentaron impulsar una nueva acción sindical de tipo confesional ${ }^{44}$, reforzada en el campo y comenzada ex novo en los núcleos urbanos y, por supuesto, la creación de un auténtico partido político: Acción Popular, creado, dotado de pensamiento y encauzado políticamente por El Debate. Se trataba con todas estas herramientas de mostrar la fuerza, vitalidad e importancia del catolicismo español.

\footnotetext{
${ }^{43}$ AHN, archivo carlista Borbón-Parma, correspondencia de Alfonso Carlos I, c. 105, exp. 5.

44 A partir de 1932, Acción Católica se colocó fuera del ámbito de acción política y sindical para las que los católicos crearon otras plataformas específicas y autónomas. Las bases insistieron precisamente en conceder a las obras económico-sociales, es decir a los sindicatos, un estatuto flexible de integración y relación con el conjunto de la Acción Católica, a través de un secretariado de obras económico-sociales. F. MonTERo, El movimiento católico en España, Madrid, Eudema, 1993, p. 65.
} 


\section{MeMORIA CARLISTA DE LA REVOLUCIÓN DE 1868 EN 1931}

Si bien en aquellos años, como consecuencia de la oleada ideológica antidemocrática instalada en Europa, el joven español podía ser antiliberal y moder${ }^{n}{ }^{45}$, el carlismo testimonió su identidad decimonónica para presentarse como el constante $-\mathrm{y}$ por ello el único auténtico- enemigo del liberalismo. De esta manera, la prensa legitimista, a través de editoriales y artículos de opinión, no cesó, durante el primer año republicano, de recordar a sus lectores los evidentes paralelismos que existían entre la España de la Gloriosa Revolución y la Segunda República. Su innegable finalidad era perpetuar un momento de esplendor del carlismo, previo al estallido de la Tercera Guerra (1872-1876), animando a sus lectores a evocar a sus antepasados y preparar otro alzamiento contra la «degeneración del liberalismo» que, en aquellos momentos, finalizaría de seguro con el establecimiento de un régimen comunista ${ }^{46}$. En 1873, el régimen democrático había degenerado con la proclamación de la anárquica Primera República, como Incógnito Leal se encargó de recordar en su artículo « $L a$ Historia se repite. La República en Cataluña y en Vasconia ;Todo un símbo$l o ! \gg 47$.

Para acentuar ese paralelismo, y, al mismo tiempo, reafirmar la identidad carlista decimonónica en las nuevas generaciones, se volvieron a publicar antiguos manifiestos políticos de Carlos VII contra la ilegitimidad de los gobernantes ${ }^{48}$, artículos del escritor Francisco Navarro Villoslada con el significativo título «Hoy como ayer. El hombre que se necesita», afirmaciones de tradicionalismo como contrarréplica a las acusaciones de absolutismo, al igual que en los años del Sexenio Democrático ${ }^{49}$. El famoso panfleto de la época amadeísta « $O$ don Carlos o el petróleo!» fue sustituido, en los años republicanos, por ${ }_{i} i O$ los tradicionalistas o el caos!!» y « $; O$ comunismo o Jaimismo!» ${ }^{50}$. Si el ideal contrarrevolucionario español encontró en los años isabelinos su expresión más coherente en el pensamiento de Juan Donoso Cor-

45 P. C. González Cuevas, Historia de las derechas españolas, Madrid, Biblioteca Nueva 2000, p. 294.

46 «El régimen liberal» por J. de Arco, El Cruzado Español, 17 de abril de 1931, p. 3; «El comunismo acecha» firmado por J. Ramiro, El Cruzado Español, 3 de julio, p. 7.

${ }^{47}$ El Cruzado Español, 24 de abril de 1931, p. 7.

48 «Manifiesto a los españoles de 1868», El Cruzado Español, 17 de abril de 1931, p. 1; «La Tradición contra la proclamación de D. Amadeo. La Tour, 1870», «Contra la proclamación de Alfonso XII. Lucena, 1875», El Cruzado Español, p. 4 y 5.

49 «Aspiraciones tradicionalistas. Lo que somos y queremos», El Cruzado Español, 17 de abril de 1931, p. 7; «Ante el porvenir. Unión y acción», «La Tradición contra la proclamación de D. Amadeo», El Cruzado Español, 24 de abril, p. 1; «Retrato de D. Jaime de Borbón. El hombre que España necesita en los momentos críticos de su existencia. Manifiesto desde París», El Cruzado Español, 1 de mayo, p. 1.

${ }^{50}$ Artículo firmado por Modestinus, El Cruzado Español, 8 de mayo de 1931, p. 1; El Cruzado Español, 29 de mayo, p. 3.

Hispania Sacra, LIX

119, enero-junio 2007, 337-361, ISSN: 0018-215-X 
tes y Jaime Balmes, sus obras volvieron a reeditarse, bajo el prisma carlista, en los años de la Segunda República. En 1932, los Pensamientos de Balmes fueron editados por Nueva Biblioteca Filosófica, además de un Ideario de Donoso Cortés de A. Porras, Balmes, la seva vida del sacerdote Ignacio Casanovas y Balmes, conductor d'esperits de José María Ruiz Manent. Al año siguiente, apareció la obra de J. Faurey, La Philosophie politique de Balmes conjuntamente con numerosos libros sobre la interpretación tradicionalista de los conflictos bélicos carlistas y sus líderes con motivo del I Centenario de la Guerra de los Siete Años ${ }^{51}$.

$\mathrm{Y}$, al igual que durante los años del Sexenio Revolucionario, la prensa carlista asumió el papel de conseguir mayores apoyos, ganando para la causa a numerosos católicos, a través de la constante denuncia y crítica de la política religiosa de la Segunda República. En este sentido, la falta de tacto y los propios errores de las autoridades republicanas a la hora de resolver las cuestiones relacionadas con la Iglesia católica, en cierto modo, facilitaron su misión. Los periódicos carlistas volvieron a unir la defensa de la Iglesia católica con la afirmación de la unidad y esencia de España, subrayando su utilidad como muro de contención frente a la ola bolchevique que amenazaba Europa y la necesidad de apuntalarla nuevamente frente a la política anticlerical de las autoridades y fuerzas políticas republicanas. Como la tutela más auténtica, verdadera y adecuaba la realizaban los carlistas -autoproclamados en su prensa como Guardia Civil de la Iglesia-, no se cesó de realizar constantes llamadas a los católicos, durante los siguientes meses, para unirse a las filas de D. Jaime y, su sucesor, D. Alfonso Carlos I.

Si en 1868, la proclamación de la libertad de cultos y de enseñanza fue denunciada por los carlistas como una disposición atentatoria de base contra la religión y la esencia católica de los españoles ${ }^{52}$, en 1931 volvieron a afirmarlo, denunciando reformas republicanas como la voluntariedad de los actos católicos en el Ejército, la inasistencia de autoridades en manifestaciones religiosas públicas, la separación Iglesia-Estado, la secularización de cementerios y la reintegración del clero a su plenitud civil ${ }^{53}$. Para escándalo de algunos tradicionalistas, ni los padres de la Constitución de 1869 se habían atrevido a esos extremos, que trataban de emular la descristianización defendida por los jacobinos durante la Revolución Francesa ${ }^{54}$. De ahí que ciertos carlistas anunciaran

51 Ver «Apéndice I, Obras tanto carlistas como liberales publicadas» en M. FERrER, Historia del Tradicionalismo Español, tomo XXX, vol. II, Sevilla, Ed. Católica Española 1979, pp. 121-134.

52 La Esperanza, 15, 20 y 21 de octubre de 1868.

53 «Contra todo despotismo. La soberanía nacional y la suprema tiranía» por Diego de Miranda y «Más botones de muestra. Orientaciones del Gobierno Provisional», El Cruzado Español, 24 de abril de 1931, p. 2; «Oro viejo. La falsa e inaguantable soberanía popular» de Augusto Nicolás, en el número 93,1 de mayo, p. 6.

54 En su artículo «Apuntaciones y comentarios. Por dónde va la República», Goiriz comparó las medidas anticlericales de 1868 con las previstas por los republicanos en 1931. No tenía sentido la li- 
-a medio plazo- el estallido de una persecución religiosa, medida que llevaría a la revolución social, al ser el catolicismo la única providencia que podía garantizar, al mismo tiempo, la felicidad y el orden, frente al auge del socialismo y el colectivismo ${ }^{55}$. El extremismo imperó en numerosos colaboradores y periodistas, elevando el tono de las críticas y publicando artículos con títulos excedidos como «¿No reaccionamos?... ante el Imperio de Luzbel» o «Aviso del Cielo ¡Medite! ¡Encomiéndese! ¡Vuelva a Dios!» ${ }^{56}$. Contrastando los artículos de La Esperanza con los de El Cruzado Español, a pesar de mantener la misma línea ideológica, el estilo periodístico había resultado mucho menos exaltado en el periódico decimonónico que en el segundo.

Durante la última etapa del reinado de Isabel II, el régimen se había acercado al máximo a la Iglesia, aumentando la confesionalidad del Estado a ojos de numerosos liberales progresistas, aproximación que también fue atribuida a Alfonso XIII en la postrera etapa del suyo ${ }^{57}$. Como consecuencia, la oposición política había alzado, aún más alto, la bandera del anticlericalismo para obtener apoyos sociales entre quienes creían que el régimen monárquico había caído en uno de los postulados esenciales del carlismo: una más que estrecha unión entre la Iglesia y el Estado. Sin embargo, la prensa carlista, tanto en 1868 como en 1931, al volverse a proclamar como exclusiva bandera católica, intentó justificar la caída de la Monarquía constitucional como un hecho consustancial a sus orígenes liberales ${ }^{58}$. Lógicamente, según sus postulados, no podían admitir que la Corona defenestrada hubiera sido fuertemente criticada por su excesivo celo

bertad de cultos pues las minorías protestantes no eran importantes; la secularización de cementerios en poblaciones mayores de 600 vecinos o cabezas de partido ya estaba prevista por una ley de 1883 y la laicización del papel oficial -supresión de alusiones a Dios guarde a usted muchos años-eran medidas extremas. El Cruzado Español, 24 de abril de 1931, pp. 5 y 6.

55 «En esta hora. Frente al Imperio del odio y de la rebeldía estará siempre la Monarquía Tradicional», de J. de Arco, El Cruzado Español, 1 de mayo de 1931, p. 2 y, en el mismo número, «Lo más trascendental. Influencia del periodismo», de Jaime Leal de la Alcarria, p. 3.

${ }^{56} \mathrm{El}$ primero firmado por Modestinus, El Cruzado Español, 15 de mayo de 1931, p. 1; el segundo por Fontnouva, en su número 102, 3 de julio de 1931, p. 7.

${ }^{57} \mathrm{El}$ acercamiento está estudiado en J. de la Cueva Merino, «El Rey Católico» en J. Moreno LuZÓN (Dir.), Alfonso XIII. Un político en el trono, Madrid, Marcial Pons 2003, pp. 277-306. Sobre la etapa anterior al Sexenio, J. M. CUENCA TORIBIO, «El catolicismo español en el reinado de Isabel II: una panorámica» en sus Estudios sobre el catolicismo español contemporáneo. IV, Córdoba, Universidad de Córdoba 2005, pp. 57-80.

${ }^{58}$ La Esperanza afirmó, de forma insistente, que Isabel II había sido arrastrada por los mismos liberales que la alzaron, en sus números de 20 y 28 de octubre, 4 de noviembre, 2 y 13 de diciembre de 1868. El Cruzado Español publicó ataques y críticas contra Alfonso XIII -de diferente intensidad-el 17 de abril de 1931; el 24 de abril se reunieron varios como «La caída del régimen ¡Pusilánime! ¡Inconfeso!», firmado por Torres de Navarra; «Derechas y derechos. Republicanos o jaimistas» de Constancio, el 1 de mayo; «iSe fue por fin!» por Iñigo de Vasconia, 15 de mayo; y 22 de mayo. Las críticas contra el rey exiliado menguaron a partir de la expulsión del cardenal Segura y los acercamientos entre la dinastía carlista y la liberal en el último semestre del año. Menor crítica ante el monarca caído tuvie-

Hispania Sacra, LIX

119, enero-junio 2007, 337-361, ISSN: 0018-215-X 
religioso, ya que ello les detraería apoyos electorales. De esa manera, los semanarios carlistas presentaron a la Monarquía Tradicional como la auténtica y única opción monárquica y católica.

No obstante, si en 1868, la prensa tradicionalista defendió, a través de numerosas argumentaciones, la idea de que en España no había una mayoría republicana sino monárquica -que debía elevar al trono a Carlos VII-, en 1931 resultó necesario a sus redactores explicar a los lectores la victoria anticlerical y republicana en las elecciones municipales. La prensa jaimista trató de justificar este triunfo político por la falta de sinceridad y práctica religiosa de las clases propietarias, ya que -al no ejercer la caridad y la justicia evangélica con sus empleados, criados y trabajadores- habían favorecido la expansión del republicanismo, la clerofobia y el comunismo entre ellos.

«Rentas abusivas, jornales mezquinos, jornadas agotadoras, agiotismo, especulación de un lado. Afán de lujo y de placeres, vanidades, incomprensión por otro. Nada de esto lograron cambiar en esta sociedad, más materializada cada día, las luminosas Encíclicas de sapientísimos pontífices; ni las predicaciones de tantas comunidades religiosas, que presto la Revolución hará desaparecer, esparcidas por toda la Península y en trato frecuente con los grandes y poderosos; ni la sabiduría ni autoridad de los prelados (...). La $\mathrm{Fe}$ agonizaba en los corazones, pese a las prácticas de una piedad externa ¡Hay por lo visto una religión para los capitalistas y otra la cristiana, para consuelo de los humildes y los necesitados, a fin de que inspire en éstos sentimientos de resignación a la vista de la orgía mundana!»59.

Por eso la llegada de la Segunda República fue interpretada como un aviso o castigo de Dios a la sociedad española, como el propio jefe de la secretaría política de D. Jaime y su máximo representante en España, marqués de Villores, llegó a afirmar con sumo convencimiento pública y privadamente. El 22 de mayo de 1931 escribió al Pretendiente desde Valencia:

«Si leéis los artículos de UN ERMITAÑO glosando el Evangelio, en EL TRADICIONALISTA, que son míos, habréis observado el tiempo que vengo anunciando los acontecimientos actuales, principio del castigo que Dios nos envía y que se convertirá en terrible, pero corto, no creo que dure más allá de siete meses. Tras de ese castigo si el Rey y todos los leales procuramos hacernos muy muy de Dios, triunfaremos con D. Jaime y si no con quién Dios disponga» ${ }^{60}$.

ron El Siglo Futuro y Criterio. Sin embargo, El Cruzado Español, en los años republicanos, siempre se negó a la fusión dinástica de las dos ramas.

59 «Examen de conciencia», J. de Arco, El Cruzado Español, 8 de mayo de 1931, p. 4.

${ }^{60} \mathrm{AHN}$, archivo carlista Borbón-Parma, correspondencia de Alfonso Carlos I, c. 105, exp. 2. 
De ahí que los periódicos legitimistas publicaran artículos donde afirmaban que la Iglesia no había sido defendida por los Gobiernos alfonsi$\operatorname{nos}^{61}$. Y de esta manera, intentaron menospreciar al máximo los últimos acercamientos católicos de isabelinos y alfonsinos, aunque sus élites dirigentes admitieran, privadamente, que esa postura les había valido el abierto apoyo de las jerarquías eclesiásticas y del Vaticano, tanto en el siglo XIX como en el XX. De ahí la insistencia de los jaimistas por conseguir ese mismo apoyo, a través de sus continuas afirmaciones en defensa del catolicismo. No sólo buscaron ampliar sus bases sino también obtener el apoyo explícito de la jerarquía. En este sentido, la prensa carlista intentó no desaprovechar la ocasión para defender al cardenal Segura de las acusaciones de las autoridades republicanas, al ser el único prelado ardorosamente tradicionalista, aunque alfonsino ${ }^{62}$.

\section{Una DifERENCIA INESPERADA CON 1868: LA EXPUlsión DEL CARDENAL PRIMADO}

El 2 de mayo de 1931 se prohibió la venta o transferencia de propiedades de la Iglesia y, sólo cuatro días más tarde, se puso fin a la enseñanza religiosa en las escuelas públicas. El arzobispo de Toledo y primado se pronunció oficialmente ante el nuevo régimen mediante una carta pastoral que motivó la protesta de las autoridades republicanas. El documento pastoral fue publicado en la prensa católica, lo cual no ayudó a apaciguar las críticas republicanas ${ }^{63}$. Los carlistas acusaron al Gobierno Provisional de fomentar -a través de su prensauna campaña difamatoria contra el cardenal primado, Pedro Segura, conocido por sus tendencias tradicionalistas e integristas. El Siglo Futuro negó impulsivamente que el purpurado hubiera dicho o realizado algún acto de hostilidad contra el régimen republicano ${ }^{64}$. La prensa conservadora denunció una campaña del ministro de Justicia contra el cardenal a la que se sumaron integristas, mellistas y jaimistas.

\footnotetext{
${ }^{61}$ Ideas que se repitieron en varios meses en los siguientes artículos: «El poder del dinero. El castigo de lo Alto», El Cruzado Español, 17 de abril de 1931, p. 7; «Ellos y nosotros. La justicia de Dios ¡Impenitentes! ¡Ciegos!» por Dolores de Gortázar, 24 de abril, p. 8; «Ellos y nosotros ¡Esa es la lealtad!» por Vicente Torres, 1 de mayo, p. 5.

${ }^{62}$ Sobre este prelado se han publicado, en los últimos años, varios estudios F. Gil Delgado, Pedro Segura. Un cardenal sin fronteras, Madrid, Biblioteca de Autores Cristianos 2001, y S. MARTínez SÁNCHEZ, Los papeles perdidos del cardenal Segura, 1880-1957, Pamplona, Eunsa 2004.

63 «Deberes de los católicos en la hora actual. Importante carta del eminentísimo señor cardenal primado, arzobispo de Toledo, director pontificio de Acción Católica en España», El Siglo Futuro, 6 de mayo de 1931, p. 1.

64 «La campaña de difamación y calumnia contra el cardenal primado» y «La campaña calumniosa contra el Emmo. cardenal primado», El Siglo Futuro, 25 y 28 de abril de 1931.
} 
Los telegramas de apoyo al purpurado enviados por agrupaciones y juntas tradicionalistas se sucedieron en los siguientes días. Pero la tensión entre monárquicos y anticlericales estalló con los famosos incendios del 11 al 14 de mayo en varias ciudades. Los incidentes y las vacilaciones gubernamentales a la hora de reprimirlos confirmaron las sospechas católicas ante la República y otorgaron fuerza a los carlistas que denunciaron la falta de seguridad de la Iglesia y de orden público ${ }^{65}$. La prensa jaimista redundó en los hechos durante varios días, sobre todo tras la acusación del Gobierno contra el cardenal Segura, a quien se responsabilizó de los disturbios y se le ordenó abandonar el país. La marcha del purpurado y la del monárquico obispo de Vitoria, Múgica, fueron denunciadas por los carlistas como un intolerable atropello gubernamental contra la privilegiada posición de la jerarquía eclesiástica ${ }^{66}$, al que debía unirse los anunciados decretos sobre libertad religiosa y expulsión de imágenes religiosas de los centros educativos públicos. La exclusión del crucifijo fue considerado por los legitimistas como un acto simbólico de enorme significación, apareciendo sendas protestas contra el ambiente anticlerical en las juntas locales carlistas y en las bases, así como en sus periódicos. Los tradicionalistas comenzaron a experimentar un proceso de radicalización más agudo que en los años anteriores y que, en los venideros, les abriría la vía de la insurrección armada.

Dirigentes tradicionalistas como Víctor Pradera, el conde de Rodezno, Sánchez Marco, Arturo Campión y otros representantes navarros protestaron contra la medida tomada contra el cardenal Segura ${ }^{67}$. Si bien el hecho no radicalizó a los hombres de Acción Nacional, los tradicionalistas intentaron limar sus diferencias y acentuar la unión de las derechas católicas. Un mitin fuerista celebrado en la Plaza de Toros de Pamplona fue la confirmación pública de la voluntad unitaria de las tres ramas tradicionalistas. Más de 25.000 asistentes escucharon a los jaimistas marqués de Villores, Beunza y Díaz de Aguado, al integrista Senante y al mellista Tellería. Los discursos se centraron, predominantemente, en la defensa de los valores católicos atacados por los nuevos poderes republicanos $^{68}$. En un segundo término, los oradores se solidarizaron con la asamblea estatutaria convocada en la misma fecha por los municipios vascos en Estella.

Sin embargo, tras los sucesos de mayo, la mayoría del episcopado mantuvo una actitud -al menos públicamente- de discreción y moderación, de acuerdo

65 «Los sucesos del domingo y del lunes. Iglesias, conventos y asilos quemados en Madrid y provincias», El Siglo Futuro, 12 de mayo de 1931, p. 1.

${ }^{66}$ Se subrayó el hecho de que dos miembros del Comité de Defensa de la República, por orden del Gobierno, acompañaran a la policía española hasta la frontera francesa como testigos de la salida del cardenal Segura. El Siglo Futuro y El Pensamiento Navarro, 15 y 25 de mayo de 1931.

${ }^{67}$ El Pensamiento Navarro, 28 de junio de 1931, p. 2.

${ }^{6}$ El Pensamiento Navarro, 16 de junio de 1931, p. 1. La declaración colectiva pastoral apareció firmada por el Primado y ocho prelados más. 
con las instrucciones vaticanas, e igualmente moderada fue la reacción ante uno de los decretos con que se inició la labor legislativa del Gobierno Provisional y por el que se puso fin a uno de los privilegios de la Iglesia más firmes, al establecer la libertad de creencias y cultos. Salvo el documento que, en nombre de todo el episcopado, suscribió el cardenal Segura el 3 de junio ${ }^{69}$, la protesta particular del cardenal Vidal y Barraquer, la pública del obispo Álvarez Miranda y alguna alusión aislada en el contexto del tratamiento de otros temas, en los Boletines Eclesiásticos no se publicó ninguna contestación del episcopado ante esta norma ${ }^{70}$.

Finalmente, en las elecciones celebradas el 28 de junio de 1931 para Cortes Constituyentes, los carlistas lograron, en sus zonas de influencia, cinco representantes en el marco de una coalición con católicos independientes y nacionalistas. La colaboración con éstos últimos en el País Vasco no se limitó a los comicios, sino que fue asimismo significativa la campaña para la elaboración de un estatuto de autonomía, proyecto en el que ambas fuerzas se necesitaban. Los tradicionalistas vieron en el estatuto la posibilidad de preservar Navarra y las provincias vascas de influencias laicas e izquierdistas, como en 1868 habían sido «reserva espiritual» de una España católico-monárquica. Sin embargo, el proyecto no prosperó, las diferencias políticas entre nacionalistas vascos y carlistas fueron emanando hasta llegar a la confrontación. En Cataluña, los carlistas concurrieron a las elecciones con la conservadora Lliga Regionalista, sin obtener ningún escaño y no tuvieron parte en la elaboración del anteproyecto del estatuto, pese a lo cual la jefatura regional, encabezada por Miguel Junyet, decidió apoyarlo en el referéndum. A fines de ese año, un grupo de carlistas abandonaron el partido para fundar, con otros nacionalistas católicos, Unió Democràtica de Catalunya ${ }^{71}$.

Los tradicionalistas comenzaron a apreciar notables diferencias con 1868, de tal manera que su prensa empezó también a comparar los hechos sucedidos esos meses con la semana trágica de Barcelona en 1909 y su oleada de sucesos anticlericales ${ }^{72}$. En este sentido recordaron el pasado agitador de Alejandro Lerroux y criticaron ácidamente a los ministros católicos del Gobierno Provisio-

${ }^{69}$ Publicado en El Cruzado Español el 26 de junio, p. 1.

${ }^{70}$ Así lo demuestra el estudio de M. C. de Frías García, Iglesia y Constitución. La jerarquía católica ante la II República, Madrid, Centro de Estudios Políticos y Constitucionales 2000.

${ }^{71} \mathrm{Al}$ año siguiente, se marcaron distancias entre la Comunión Tradicionalista y la Lliga, acudiendo separados a las elecciones autonómicas, con unos resultados decepcionantes, pese a la coalición con los alfonsinos. Un acercamiento a la óptica tradicionalista de estos hechos se puede hallar en la biografía del diputado carlista Bau, J. Monserrat CAVALler, Joaquín Bau Nolla y la restauración de la Monarquía, Madrid, Actas 2001.

72 «Tenía que suceder ¡He aquí la obra de todos!» por Goiriz, El Cruzado Español, 15 de mayo de 1931, p. 1.

Hispania Sacra, LIX

119, enero-junio 2007, 337-361, ISSN: 0018-215-X 
nal, así como a todos los políticos alfonsinos reconvertidos en republicanos ${ }^{73}$. Tras la quema de conventos en mayo, jóvenes carlistas empezaron a hacer guardia a la puerta de las iglesias y conventos de Navarra y se organizaron en la comarca de Pamplona las primeras unidades armadas de boinas rojas. La aprobación final oficial a este resurgir de la milicia carlista se produjo a mediados de junio, cuando delegados de Navarra, las provincias vascas y La Rioja se congregaron en Leiza ${ }^{74}$. Durante esa reunión, se encomendó a cinco sacerdotes párrocos la misión de aumentar el apoyo del clero navarro a la causa, aprovechando la acentuación del anticlericalismo. Por fin, frente a las manifestaciones moderadas de abril, el propio don Jaime de Borbón realizó una inequívoca manifestación antirrepublicana, intentando rentabilizar los sucesos anticlericales:

«Como particular y como jefe de nuestra Comunión, declaro que no comprendo la felicidad de España sin esa fe suya secular; que no quiero una Corona a la que la Cruz no haga sombra piadosa. Jamás conmigo el Estado será ateo y el título de cruzado del catolicismo vale más, para mí, que la Corona que heredé de mis padres» ${ }^{75}$.

El 21 de agosto tuvo lugar la primera gran suspensión de la prensa tradicionalista en toda España, por orden de las autoridades, ante los rumores de conspiración en el Norte. A ella también se acompañaron prohibiciones oficiales de manifestaciones y mítines jaimistas. Estas fueron, principalmente, las principales medidas con que las autoridades republicanas respondieron ante este rearme activista y movilizador del tradicionalismo monárquico, al que no dejaron de observar cautelosamente, pues también estaba en la memoria y formación histórica de sus dirigentes la experiencia de 1868, y el temor al fascismo no se encontraba instalado entre sus filas, a diferencia de los siguientes años.

Tras su reaparición, los periódicos carlistas acusaron de arbitrariedad al Gobierno, al que criticaron sus intentos de «apagar las voces católicas» en defensa de los intereses de la Iglesia ${ }^{76}$. A partir de entonces, los oradores carlistas hicieron más alusiones que nunca a la situación religiosa de España. Sus discursos fueron constantemente divulgados por la prensa ${ }^{77}$. Se criticó la «declaración solemne de ateísmo oficial», la disolución de la Compañía de Jesús, la nacionalización de sus bienes, el divorcio, la nueva legislación familiar y la escuela laica.

73 P.e., «iViva Cristo Rey: prohibido!», Criterio, 1 de octubre de 1931, p. 2; «Un discurso serio de veras», 15 de octubre, p. 3; «Edicto de persecución», 22 de octubre, p. 1.

${ }^{74}$ M. BlinkHoRn, Carlismo y contrarrevolución en España, 1931-1939, Barcelona, Crítica 1979, p. 98.

75 Publicado en la prensa carlista en la segunda semana del mes de julio.

76 C. BArreiro, El carlismo y su red de prensa en la Segunda República, Madrid, Actas 2003, p. 33.

${ }_{77}$ Entroncaron a la República con el ateísmo y la corrupción política, concediendo la libertad para sus seguidores y tiranizando a la oposición. El Pensamiento Navarro, 20 de noviembre de 1931, p. 3. 
Paralelamente a los debates de las Cortes Constituyentes, la prensa carlista anunció la muerte de don Jaime, los mensajes a los españoles de Alfonso Carlos I, e informó del crecimiento del movimiento legitimista ${ }^{78}$. Las críticas a Acción Nacional y Herrera Oria se acrecentaron con el comienzo del invierno desde los órganos de prensa más extremistas ${ }^{79}$.

En las Cortes, los representantes carlistas rompieron la alianza mantenida con los nacionalistas vascos ${ }^{80}$ y comenzaron a poner reparos a su participación en Acción Nacional, a la que acusaron de falta de actividad, claudicación y accidentalismo. Algunos diputados católicos expresaron, de forma terminante, su progresiva pérdida de paciencia con la República durante los debates sobre la cuestión religiosa. Uno de ellos, de la minoría vasconavarra, Beunza, concluyó su intervención con una afirmación amenazadora, y retó a la mayoría de izquierdas a que no le obligara a llevarla a la práctica:

«Si se desencadena la persecución, nos refugiaremos en nuestras montañas, y allí buscaremos el consejo de nuestra desesperación y de nuestra dignidad, como hombres libres, contra la tiranía» ${ }^{81}$.

El diputado tradicionalista Lamamié de Clairac advirtió que si se aprobaban las medidas anticlericales no tendrían más remedio que enfrentarse a esa Constitución, que no podrían aceptar. El sacerdote Antonio Pildain fue aún más explícito, al explicar que, según la doctrina católica, la lucha contra las leyes injustas podía ser expresada mediante la resistencia pasiva, mediante fórmulas activas dentro de la legalidad, o mediante la fuerza armada. Pese a que tradicionalistas como el conde de Rodezno y Víctor Pradera decidieron tomar parte en la nueva organización llamada Acción Española y colaborar en su revista, numerosos carlistas de base optaron por actuar alejados de las organizaciones alfonsinas y de las católicas accidentalistas, a las que acusaron de agudo liberalismo ${ }^{82}$.

${ }^{78} \mathrm{El}$ auge del carlismo aparece constantemente subrayado en la correspondencia entre el marqués de Villores y los Pretendientes, durante todo ese año a partir de la llegada de la Segunda República. Ver AHN, archivo carlista Borbón-Parma, correspondencia Jaime de Borbón, c. 134, exp. 3 y Alfonso Carlos I, c. 105 , exp. 3 y c. 105 , exp. 5 .

79 «La Acción Nacional y Nosotros. Frente a la táctica sutil del dardo piadoso y del retroceso continuo a que un reconocementarismo pusilánime y enfermizo invita a los católicos españoles, se levanta la Comunión Tradicionalista con sus principios, con sus soluciones y con sus procedimientos», $\mathrm{El} \mathrm{Cru-}$ zado Español, 13 de noviembre de 1931.

${ }^{80}$ Igualmente, el carlismo se distanció del PNV, sobre todo a partir de un nuevo intento por aprobar un estatuto vasco en junio. La ruptura definitiva entre carlistas y nacionalistas tuvo lugar en 1933, cuando otro proyecto de estatuto, circunscrito, en esta ocasión, a las tres provincias vascas, tampoco prosperó por la oposición expresa de la más carlista de ellas: Álava. J. L. ORELLA, op. cit, pp. 135-148.

${ }^{81}$ F. LANNON, op. cit., p. 223.

82 P. C. González Cuevas, Acción Española. Teología política y nacionalismo autoritario en España (1913-1936), Madrid, Tecnos 1998

Hispania Sacra, LIX

119, enero-junio 2007, 337-361, ISSN: 0018-215-X 
Ante la redacción de la Constitución republicana, de nuevo el cardenal Segura publicó un documento crítico, que suscribió en nombre de todo el episcopado, pero sólo tres provincias eclesiásticas -siguiendo el criterio del purpurado- enviaron mensajes a las Cortes con los que se intentó influir en el voto de algunos diputados. La nota característica fue la disparidad de manifestaciones en el episcopado, unas más duras y otras más moderadas ante el texto constitucional, a Ate el desconcierto de los carlistas. Todas estas voces se sellaron con la publicación del documento colectivo de 20 de diciembre de 1931 que, suscrito - esta vez totalmente- por todos los prelados, aunque dirigido en su redacción por el cardenal Vidal y Barraquer, expuso ante los fieles, con amargas y comedidas frases, la postura católica ante la nueva Ley Fundamental, y ante la legislación secularizadora dictada hasta la fecha y ratificada por las Cortes, invitando a los creyentes a una actuación más cercana a la Iglesia, tanto por medio de la intensificación de su piedad como a través de la reorganizada Acción Católica, y culminando en amargas frases relativas a la persecución experimentada por la Iglesia en España y a la esperanza en un futuro de mayor armonía ${ }^{83}$.

\section{EN CONCLUSIÓN}

Uno de los elementos de transmisión entre el carlismo decimonónico y el carlismo del siglo XX fue, sin duda, la prensa, especialmente a través de sus recordatorios documentales y gráficos de su pasado idealizado. Se trató, durante los años republicanos, de evitar que muchos miembros de la Comunión se consideraran antes tradicionalistas que propiamente carlistas. Es decir, depositarios de un poso de experiencia antes que afines a una causa dinástica con sus símbolos y estandartes ${ }^{84}$. De ahí, entre otros recordatorios, su defensa militante del catolicismo y los iniciales paralelismos entre la llegada del régimen republicano y La Gloriosa Revolución.

Las fuerzas políticas carlistas en 1931, pese a todos sus esfuerzos y declaraciones, no lograron el sostén palmario o indirecto de ningún obispo ni arzobispo español, y no se publicaron cartas de protesta semejantes a las de 1868 en sus periódicos. Tan sólo aparecieron en sus páginas resúmenes de encíclicas papales -como la Quadragessimo anno de Pío XI- o la declaración colectiva del Primado y ocho prelados más el 26 de junio de 1931, pero nunca en con carác-

${ }^{83}$ M. C. FRÍAS GARCÍA, Ibid., p. 727.

${ }^{84}$ Como señala Javier Ugarte, en los años treinta, muchos nuevos carlistas se sintieron unidos a una comunidad de adhesión voluntaria más que a una comunidad de vida, art. cit., p. 182. 
ter exclusivo. Fuera de Navarra, Cataluña, La Rioja y el País Vasco muy pocos sacerdotes se manifestaron públicamente por la opción carlista durante 1931. El presbítero tradicionalista Vicente Torres Espejo intentó en Madrid, desde las páginas de El Cruzado Español, constituir una agrupación católica para defender la presencia pública de la Iglesia, a la que bautizó como Los Cruzados de Cristo ${ }^{85}$. Su proyecto no tuvo éxito, pese a la propaganda que le otorgó su detención por la policía republicana ${ }^{86}$. La jerarquía eclesiástica se negó a conceder al tradicionalismo monárquico el monopolio de la representación política del catolicismo militante en España, una postura que perpetuó la enarbolada durante la Restauración borbónica. Esta generación de prelados ya había asumido totalmente los cambios históricos derivados de la revolución liberal del siglo XIX, a diferencia de la generación de obispos de 1868, nacidos la mayoría en el Antiguo Régimen, siendo testigos de la posibilidad de una resistencia social al cambio político durante la Primera Guerra Carlista.

No obstante, el catolicismo político y el carlismo comprendieron, en 1931, que la cuestión religiosa era una polémica sumamente útil para la movilización de la derecha, especialmente entre el campesinado y la burguesía conservadora, en la oposición a las reformas republicanas, por lo que vincularon la nueva legislación con la masonería y el comunismo. El cosmos católico emergió más dinámico que nunca, después de que la República le hubiera cerrado numerosas puertas en ese año ${ }^{87}$.

No se puede dudar de que el carlismo fue una de las opciones más ágiles y tempranas del catolicismo militante, pero no pudo lograr el privilegio exclusivo de su bandera. La convergencia con los nacionalismos cristianos vasco y cata-

85 «Los Cruzados de Cristo», por V. Torres Espejo, El Cruzado Español, 22 de mayo de 1931, p. 7. La agrupación reuniría a católicos de ambos sexos, sin distinciones políticas, bajo el patronazgo del arcángel San Miguel, príncipe de las milicias celestiales.

86 Tras su detención fue entrevistado por El Cruzado Español, 15 de junio de 1931, pp. 1 y 2. La policía le detuvo en su casa, donde tenía 8.000 hojas de propaganda católico-patriótica, y le llevó a comisaría, donde, tras ser interrogado durante tres horas, le pusieron en libertad. El sacerdote Vicente Torres Espejo fue miembro de la Adoración Nocturna Española, adscrito a la parroquia de San Ginés y primer presidente del centro parroquial de la Juventud Católica de Nuestra Señora de Covadonga de Madrid, fundada en febrero de 1932. Al estallar la Guerra Civil, fue asesinado el 12 de noviembre de 1936. Archivo General de la Administración, (8) 30. SIG 36/115, página del registro de asociaciones 3947; J. F. GuiJarro, Persecución religiosa y guerra civil. La Iglesia de Madrid, 1936-1939, Madrid, La Esfera de los Libros 2006 p. 470. Agradezco a Álvaro Feal la información suministrada sobre este sacerdote.

${ }^{87}$ Incluso en zonas sumamente conflictivas como el Sur peninsular se observó ese renacimiento, como concluyen L. ÁLVAREZ REY, «El carlismo en Andalucía durante la II República (1931-1936)», en A. Braojos, et al., Sevilla, 36: sublevación fascista y represión, Brenes, Muñoz, Moya y Montraveta, 1990, pp. 17-79; Id., «La contribución del carlismo vasconavarro a la formación del tradicionalismo en Andalucía (1931-1936)», Príncipe de Viana, 10, (1988), pp. 23-32; y J. M. Macarro Vera, Socialismo, República y revolución en Andalucía (1931-1936), Sevilla, Universidad de Sevilla 2000.

Hispania Sacra, LIX

119, enero-junio 2007, 337-361, ISSN: 0018-215-X 
lán le generó más decepciones y enfrentamientos que resultados positivos, y la apuesta de acercamiento y colaboración con las autoridades republicanas del papa Pío XI, a través de su nuncio Federico Tedeschini, se impuso en la jerarquía española. De esta manera, la actitud de la Santa Sede llegó a ser considerada por los carlistas como una «defección», a diferencia del pontificado de Pío IX, contemporáneo a La Gloriosa ${ }^{88}$. Los afanes tradicionalistas para monopolizar el voto católico comenzaron a naufragar así, poco a poco, hecho que asumieron sus élites rectoras a partir de la victoria electoral de la CEDA dos años más tarde.

${ }^{88}$ Hecho que subraya J. M. CUENCA TORIBIO, «Pío XI y el episcopado español» en Estudios sobre el catolicismo español contemporáneo. IV, Córdoba, Universidad de Córdoba 2005, pp. 109-124. Ver, asimismo, Achille Ratti pape Pie XI. Actes du colloque organisé par l'École française de Rome (Rome, 15-18 mars 1989), Roma, colección de la École Française de Rome, 223, 1996, pp. 811-824. 